\title{
Evaluation of emergency operations and anesthesia procedures used in surgical emergencies before and during the COVID-19 pandemic
}

\author{
D Tümay Uludağ Yanaral, M.D., (1) Hüseyin Öz, M.D.
}

Department of Anesthesiology and Reanimation, İstanbul Medipol University Faculty of Medicine, İstanbul-Turkey

\begin{abstract}
BACKGROUND: The number of people actively participating in society has decreased following the coronavirus disease 2019 (COVID-19) pandemic as a result of the measures taken to reduce the risk of transmission, such as interruption to education, social isolation, and curfews. Accordingly, change in the etiology of emergency surgery and characteristics of patients may be expected. The current study aimed to compare emergency surgery between the COVID-19 pre-pandemic and pandemic periods and to present the data and emergency anesthesia management of patients with suspected COVID-I9.
\end{abstract}

METHODS: Patients who underwent emergency surgery in our hospital between January 22 and April 29, 2020, were examined retrospectively. The patients were divided into two groups: Those operated before March II, 2020 (Group I) and those operated from this date April 29, 2020 (Group 2). The data of the two groups were compared. Routine emergency anesthesia and surgical approach were applied to all patients in Group I and those without suspected COVID-19 in Group 2. Patients with suspected COVID-I9 in Group 2 were treated with an algorithm created in accordance with the guidelines of official institutions and scientific associations.

RESULTS: Age, gender, chronic medical diseases, ASA classification, Mallampati score, surgical department, surgical procedures, surgical etiology, duration of surgery, and length of hospital stay were similar in both groups. The number of patients undergoing general anesthesia and spinal anesthesia was 198 (82.5\%) and 42 (17.5\%) for Group I while it was I6I (73.9\%) and 57 (26.1\%), respectively, for Group 2 ( $p=0.025)$.

CONCLUSION: The clinical data and surgical features of emergency patients during the pandemic were similar to those before the pandemic; however, the rate of spinal anesthesia was higher in the former. Personal protective equipment standards should be followed to prevent cross-infection among the anesthesiology team during anesthesia procedures for emergency operations. We consider that necessary emergency interventions can be safely performed and COVID-19 nosocomial infection can be prevented in the operating room by following the Ministry of Health recommendations and guidelines that are updated regularly.

Keywords: Anesthesia; coronavirus infections; COVID-19; emergencies; surgery.

\section{INTRODUCTION}

Emergency anesthesia can be defined as anesthesia administered during a surgical operation that is performed to deal with an acute threat to life, organs, limbs, or tissues. Emergency patients are difficult to manage for an anesthesiologist. They require careful evaluation and special treatment. The incidence and severity of anesthesia complications are higher compared to elective surgery, and usually emerge as hemodynamic and airway-related disorders. Emergency surgery is classified as traumatic and non-traumatic. Traumatic emergency surgery is performed at a rate of 2.2-12.1\%, depending on the income level of countries. ${ }^{[1]}$

Coronavirus outbreaks seem to have had the most significant impact on human health in the $2 \mathrm{I}^{\text {st }}$ century. Coronavirus

Cite this article as: Uludağ Yanaral T, Öz H. Evaluation of emergency operations and anesthesia procedures used in surgical emergencies before and during the COVID-19 pandemic. Ulus Travma Acil Cerrahi Derg 2021;27:639-646.

Address for correspondence: Tümay Uludağ Yanaral, M.D.

İstanbul Medipol Üniversitesi Tıp Fakültesi, Anesteziyoloji ve Reanimasyon Anabilim Dalı, İstanbul, Turkey

Tel: +90 505 - 2422100 E-mail: uludagt@yahoo.com

Ulus Travma Acil Cerrahi Derg 2021;27(6):639-646 DOI: 10.14744/tjtes.2020.43678 Submitted: 02.06.2020 Accepted: 06.08.2020

Copyright 2021 Turkish Association of Trauma and Emergency Surgery 
disease 2019 (COVID-19) has emerged as a strain of severe acute respiratory syndrome coronavirus. ${ }^{[2]}$ The disease, first detected in Wuhan, the capital of Hubei province of China in December 2019, later turned into a global health problem. The World Health Organization declared this outbreak an international public health emergency on January 30 , 2020, and a pandemic on March II, 2020. ${ }^{[2]}$ On the same date, the Turkish Ministry of Health reported the first case of COVID-19 in Turkey. Anesthesiologists are at higher risk for COVID-19 than other healthcare professionals as they perform intubation and respiratory management. Anesthesia management algorithms and guidelines have been published by official institutions and scientific associations with the aim to reduce this risk. ${ }^{[3-5]}$

The number of people actively participating in society has decreased following the COVID-19 pandemic as a result of the measures taken to reduce the risk of transmission, such as interruption to education, social isolation, and curfews. Accordingly, change in the etiology of emergency surgery and characteristics of patients may be expected. The current study aimed to compare emergency operations performed in the pre-pandemic and pandemic period of COVID- 19 and to present the data and emergency anesthesia management of patients with suspected COVID-19.

\section{MATERIALS AND METHODS}

\section{Study Design and Patients}

After obtaining institutional approval (Approval number: 2020/387), patients who underwent emergency surgery in our hospital between January 22 and April 29, 2020, were retrospectively examined 7 weeks before and after March I I, 2020, based on the date when the first case of COVID-19 was reported in Turkey. The patients were divided into two groups: Those operated before March I I, 2020 (Group I) and those operated from this date to April 29, 2020 (Group 2). The electronic medical records and anesthesia records of all patients and chest X-ray and/or chest computed tomography (CT) images of patients with suspected COVID-19 were evaluated. The patients' demographics, pre-operative status, anesthesia and surgical data, COVID-19 assessment, and clinical results were recorded. The data of the two groups were compared.

Routine emergency anesthesia and surgical approach were applied to all patients in Group I and those without suspected COVID-19 in Group 2. Patients with suspected COVID-19 in Group 2 were treated as follows.

\section{Preparation for the Procedure}

All emergency procedures were carried out in line with the algorithm created following the guidelines published by the Turkish Ministry of Health and anesthesia associations following the pandemic declaration (Fig. I)..$^{[3-5]}$ For patients with suspected COVID-19 who were hemodynamically stable, an

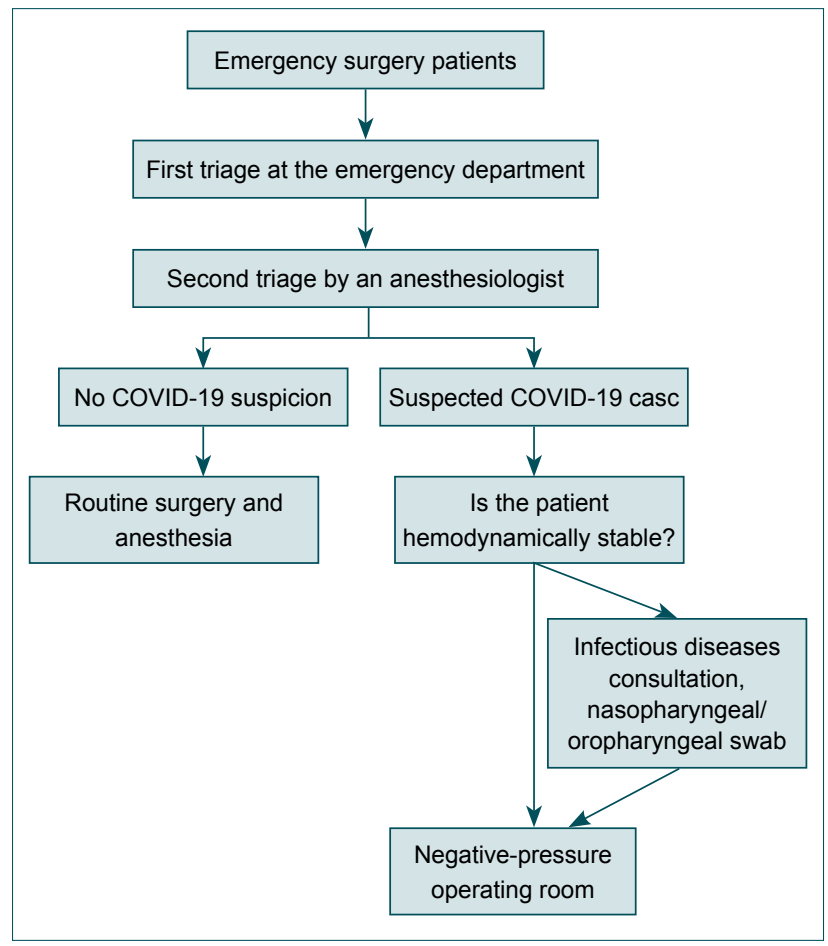

Figure 1. Flow chart of the anesthesia management for emergency procedures in patients with suspected Coronavirus Disease 2019.

infectious diseases physician was consulted, and nasal and oropharyngeal swabs were obtained. All patients were informed that the surgical intervention might negatively affect the course of possible COVID-19 infection, and their written informed consent form was obtained.

Emergency surgery patients with suspected COVID- 19 were directly taken to the negative-pressure operating theater. $A$ separate breathing circuit was used for each patient. A heat and moisture exchanger ([HME], Humid-Vent; Teleflex Medical, Co. Westmeath, Ireland) filter was placed on the inspiratory and expiratory lines of the breathing circuit and the tip of the intubation tube. Unused materials and equipment were taken out of the room, the number of people in the operating theater was kept to a minimum, and only necessary staff was allowed to be present during the procedure. All staff used personal protective equipment (PPE), consisting of impermeable coveralls, N95/FFP3 masks, goggles, face shields, gloves, and shoe covers (Fig. 2). All equipment in the room was covered with a nylon material, which was replaced after each operation (Fig. 3).

\section{Anesthesia Management}

Essential material and medications were prepared outside the operating room and placed on a Mayo table (Fig. 3). A box was assigned for contaminated items. The appropriate anesthesia method was determined according to the hemodynamic status of the patient and type of surgery. No laryngeal mask was used to reduce the risk of transmission. Oxygen was delivered with a low flow through a mask when required. 
Patients undergoing general anesthesia were intubated with rapid sequence induction (RSI) and video laryngoscopy using an intubation box or transparent shield (Fig. 3). An appropriate dose of muscle relaxant was administered to prevent the cough reflex. To avoid repeated interventions, a guidewire was placed in the intubation tube, the tip was clamped, and intubation was performed by the most experienced anesthesiologist in the team. After reaching the appropriate depth, the cuff was inflated and connected to the breathing circuit, and the clamp was removed. The location of the endotracheal tube was confirmed by capnography. During the operation, the patient's face and intubation tube were kept under a transparent cover (Fig. 2).

Spinal anesthesia and epidural anesthesia were performed with an appropriate dose of bupivacaine through the L3-L4 or L4-L5 interspace with the patients in a seated position. Prophylactic antiemetics were used to reduce the risk of vomiting and viral transmission. The patients were followed up with a surgical mask during the procedure.

Maintenance of anesthesia was achieved using heart rate, oxygen saturation, blood pressure, and end tidal carbon dioxide parameters. The patients with no post-operative indication for intensive care unit (ICU) admission were extubated under a transparent cover in the operating theater, where recovery from anesthesia occurred. The patients wearing surgical masks were directly taken to isolated rooms by staff with PPE. Intubated patients admitted to ICU were transferred with an endotracheal tube, HME filter, and bag valve tube ventilation. Disposable materials were thrown into medical

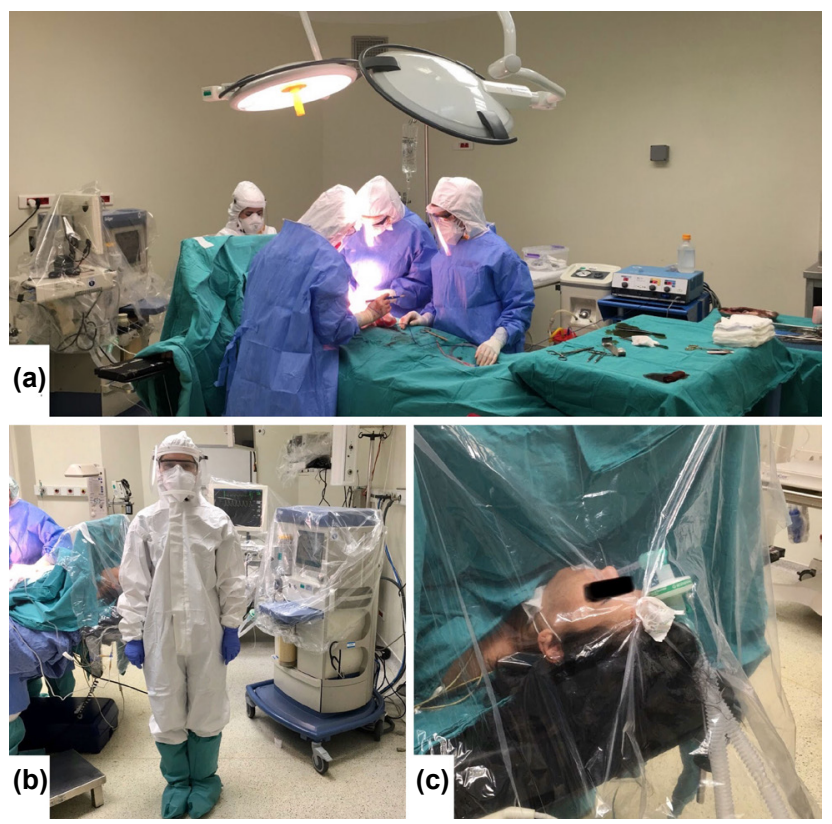

Figure 2. Photo of the operation room. (a and b) Healthcare workers performing emergency surgery wearing appropriate personal protective equipment. (c) The transparent drape used to cover the face and intubation tube during surgery. waste bags. Reusable materials and anesthetic devices were properly cleaned and disinfected.

\section{Statistical Analysis}

The Statistical Package for the Social Sciences (SPSS IBM Corp.; Armonk, NY, USA) version 22 was used to analyses the data. Independent t-test, Chi-square, and Fisher's exact tests were used to compare the groups. Quantitative data were expressed as mean \pm standard deviation values and presented in tables. Categorical data were obtained as $\mathrm{n}$ (frequency) and percentages (\%). The data were analyzed at the $95 \%$ confidence level, and the $P$ value was considered significant if $<0.05$.

\section{RESULTS}

The study included a total of 458 (130 males and 328 females) patients, of whom 240 patients were operated before March II (Group I) and 218 after March II (Group 2). The patients' age ranged from I to 77 years, with a mean value of 33.2 years. The classification of patients for pre-operative anesthetic risk assessment (American Society of Anesthesiologists [ASA]) was distributed as $71.6 \%, 22.5 \%, 5.2 \%$, and $0.7 \%$ for ASA I, II, III, and IV, respectively. The departments of obstetrics and gynecology, general surgery, and orthopedics and traumatology performed the highest number of surgical procedures with 253 (55.2\%), 67 (14.6\%), and 50 (10.9\%) operations, respectively. The most common surgical procedures were cesarean section, appendectomy and fracture fixation performed in 240 (52.4\%), 35 (7.6\%), and 25 (5.4\%) patients, respectively. Forty-six (10\%) patients underwent traumatic emergency surgery while 412 (90\%) underwent non-traumat-

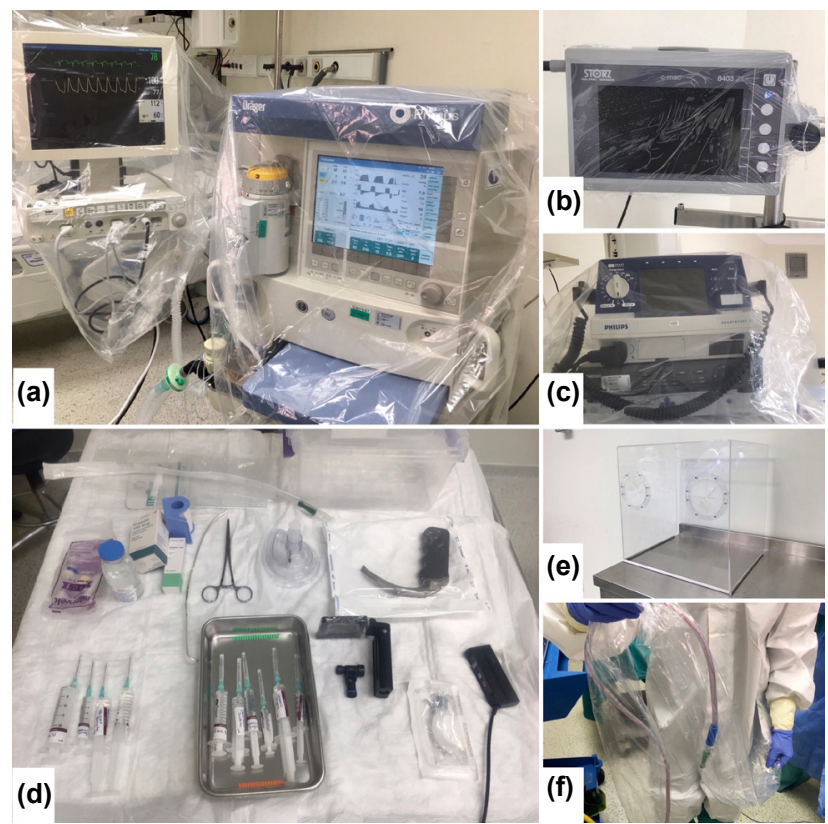

Figure 3. (a-c) Anesthesia machines protected by a single-use plastic cover to prevent contamination. (d) Airway equipment and medications prepared outside the room. (e) Intubation box. (f) Aspirator system completely covered with a disposable sheath. 
ic emergency surgery. General anesthesia was applied to 359 (78.4\%) patients and spinal anesthesia to $99(21.6 \%)$ patients. The mean operation time was 54.48 min (Table I).
Age, gender, chronic medical diseases, ASA classification, Mallampati score, surgical department, surgical procedures, surgical etiology, duration of surgery, and length of hospital

Table I. Demographic and surgery-related clinical characteristics of the patients, and their comparison between the study groups

\begin{tabular}{|c|c|c|c|c|}
\hline & $\begin{array}{l}\text { Patients } \\
(n=458)\end{array}$ & $\begin{array}{l}\text { Group I } \\
(n=240)\end{array}$ & $\begin{array}{l}\text { Group } 2 \\
(n=2 \text { I })\end{array}$ & $\mathbf{p}$ \\
\hline Age (years)* & $33.2 \pm 11.1$ & $34.8 \pm 13.1$ & $31.9 \pm 7.0$ & 0.254 \\
\hline Gender, n (\%) & & & & 0.812 \\
\hline Male & $130(28.4)$ & $71(29.6)$ & $59(27.1)$ & \\
\hline Female & $328(71.6)$ & $169(70.4)$ & $159(72.9)$ & \\
\hline Chronic medical disease, n (\%) & & & & 0.412 \\
\hline Hypertension & $58(12.7)$ & $36(15)$ & $22(10.1)$ & \\
\hline Diabetes mellitus & $19(4.1)$ & II (4.6) & $8(3.7)$ & \\
\hline Coronary artery disease & $4(0.8)$ & $2(0.8)$ & $2(0.9)$ & \\
\hline ASA classification, $\mathrm{n}(\%)$ & & & & 0.286 \\
\hline 1 & $328(71.6)$ & $167(69.6)$ & $161(73.8)$ & \\
\hline II & $103(22.5)$ & $57(23.8)$ & $46(21.1)$ & \\
\hline III & $24(5.2)$ & $14(5.8)$ & $10(4.6)$ & \\
\hline IV & $3(0.7)$ & $2(0.8)$ & $\mathrm{I}(0.5)$ & \\
\hline Mallampati score, n (\%) & & & & 0.861 \\
\hline 1 & $148(32.3)$ & $76(31.7)$ & $72(33)$ & \\
\hline 2 & $260(56.8)$ & $139(57.9)$ & $|2|(55.5)$ & \\
\hline 3 & $50(10.9)$ & $25(10.4)$ & $25(11.5)$ & \\
\hline Surgical department, n (\%) & & & & 0.794 \\
\hline Obstetrics and gynecology & $253(55.2)$ & $128(53.3)$ & $125(57.3)$ & \\
\hline General surgery & $67(14.6)$ & $34(14.2)$ & $33(15.1)$ & \\
\hline Orthopedics and traumatology & $50(10.9)$ & $26(10.8)$ & $24(\mathrm{II})$ & \\
\hline Vascular surgery & $29(6.3)$ & $17(7.1)$ & $12(5.5)$ & \\
\hline Neurosurgery & $20(4.4)$ & $13(5.4)$ & $7(3.2)$ & \\
\hline Others & $39(8.5)$ & $22(9.2)$ & $17(7.8)$ & \\
\hline Procedures, n (\%) & & & & 0.210 \\
\hline Cesarean section & $240(52.4)$ & $120(50)$ & $120(55)$ & \\
\hline Appendectomy & $35(7.6)$ & $18(7.5)$ & $17(7.8)$ & \\
\hline Fracture fixation & $25(5.4)$ & $9(3.7)$ & $16(7.3)$ & \\
\hline Abscess drainage & $17(3.7)$ & $12(5)$ & $5(2.3)$ & \\
\hline Ureteral stent placement & II (2.4) & $7(2.9)$ & $4(1.8)$ & \\
\hline Others & $130(28.3)$ & $74(30.8)$ & $56(25.7)$ & \\
\hline Etiology of surgery, n (\%) & & & & 0.731 \\
\hline Trauma & $46(10)$ & $23(9.6)$ & $23(10.6)$ & \\
\hline Non-trauma & $412(90)$ & $217(90.4)$ & $195(89.4)$ & \\
\hline Anesthetic methods & & & & 0.025 \\
\hline General anesthesia & $359(78.4)$ & $198(82.5)$ & I6I (73.9) & \\
\hline Spinal anesthesia & $99(21.6 \%)$ & $42(17.5)$ & $57(26.1)$ & \\
\hline Duration of surgery (minutes) ${ }^{*}$ & $54.48 \pm 46.21$ & $54.0 \pm 43.3$ & $57.4 \pm 49.3$ & 0.756 \\
\hline Length of stay in hospital (days) & $3.1 \pm 3.3$ & $2.6 \pm 4.9$ & $3.7 \pm 0.7$ & 0.355 \\
\hline
\end{tabular}

*Mean \pm standard deviation. ASA: American Society of Anesthesiologists. 
Table 2. Demographics and clinical features of patients with suspected COVID-I 9 infection

Patients $(n=30)$

Age (years)*

$27.7 \pm 4.3$

Gender, n (\%)

Male

Female

Chronic medical disease, $\mathrm{n}(\%)$

Hypertension

Body temperature $\left({ }^{\circ} \mathrm{C}\right)^{*}$

$37.6 \pm 0.5$

Respiratory symptoms

$22(73.3)$

Chest X-ray/CT findings, $\mathrm{n}(\%)$

Ground glass opacity

$21(70)$

Consolidation

$17(56.6)$

Bronchovascular thickening

ASA classification, $\mathrm{n}(\%)$

I

II

IV

Mallampati score, $\mathrm{n}(\%)$

I

2

$20(66.7)$

Surgical department, $\mathrm{n}$ (\%)

Obstetrics and gynecology

General surgery

Urology

Orthopedics and traumatology

Others

Procedures, n (\%)

Cesarean section

Appendectomy

Fracture fixation

Ureteral stent placement

Others

Etiology of surgery, n (\%)

Trauma

Non-trauma

Anesthetic methods

General anesthesia

Spinal anesthesia

Duration of surgery (minutes)

$48.5 \pm 38.3$

Length of stay in hospital (days)

$5.2 \pm 1.6$

*Mean \pm standard deviation. ASA: American Society of Anesthesiologists.

stay were similar in both groups $(p=0.254, p=0.812, p=0.412$, $p=0.286, p=0.861, p=794, p=0.210, p=0.731, p=0.756$, and $p=0.355$, respectively). The number of patients undergoing general anesthesia and spinal anesthesia was 198 (82.5\%) and 42 (I7.5\%), respectively, for Group I, and I6I (73.9\%) and 57 (26.1\%), respectively, for Group $2(p=0.025)$ (Table I).

The demographic and clinical features of 30 patients with suspected COVID-19 are given in Table 2. The mean age of the patients with suspected COVID-19 was 27.7 years. The mean preoperative body temperature was $37.6^{\circ} \mathrm{C}$. The majority of the patients $(73.3 \%)$ had respiratory symptoms (cough, sore throat, shortness of breath, etc.). The chest X-ray and/or CT findings revealed ground glass opacity in 21 patients, consolidation in 17, and bronchovascular thickening in seven. The majority of the patients $(96.7 \%)$ had a good medical condition (ASA classification I and II). One patient who had sepsis was identified as ASA IV. The department of obstetrics and gynecology performed the highest number of surgical procedures $(n=11 ; 36.7 \%)$. The most common emergency procedure was cesarean section performed in II (36.7\%) patients. While 2 I (70\%) patients underwent general anesthesia, nine (30\%) underwent spinal anesthesia. Five (16.7\%) patients underwent traumatic emergency surgery and 25 (83.3\%) underwent non-traumatic emergency surgery (Table 2 ).

\section{DISCUSSION}

The burden of emergency surgery is much higher than other health problems that attract more attention. The annual number of deaths (about I million) in emergency surgical procedures is higher than that of maternal deaths (about 250,000). ${ }^{6]}$ General surgical emergencies constitute approximately $10 \%$ of operations in high-income countries and $21-90 \%$ in low-income countries. ${ }^{[7,8]}$ In our study, $14.6 \%$ of the operations were performed by the general surgery department, similar to the rate in high-income countries. This rate did not differ between the pre-pandemic and pandemic period (14.2\% and $15.1 \%$, respectively). The pandemic does not seem to have significantly affected the frequency of emergency surgery $(p=0.794)$.

A study from Turkey reported the rate of traumatic emergency as $41.4 \%$ and that of non-traumatic emergency as $58.5 \%$. In the same study, the emergency surgery rate was found to be $37.35 \%, 17.33 \%$, and $10.12 \%$ for the departments of orthopedics and traumatology, general surgery, and obstetrics and gynecology, respectively. ${ }^{[9]}$ The rate of emergency general surgery was similar in our study (14.6\%), but the department with the highest emergency surgery rate was obstetrics and gynecology (55.2\%). On the other hand, orthopedics and traumatology ranked third with a rate of $10.9 \%$, which explains the lower rate of traumatic surgery in our series (10\%) compared to other studies. The referral system of traumatic emergency patients may be the reason of these differences. There has been no change in the emergency etiology and procedures after the emergence of the COVID-19 pandemic $(p=0.731$ and $p=0.210$, respectively). 
Ibrahim et al. ${ }^{[10]}$ examined non-trauma emergency surgical operations among 7536 patients and reported the most common type of surgery as appendectomy with a rate of $28 \%$. While cesarean section (52.4\%) was the most common surgical procedure in our study, appendectomy ranked second at $7.6 \%$. These differences can be attributed to the type of hospitals in which the two studies were carried out. We consider that our higher rate of emergency cesarean section was due to our institution being a private university hospital. The evaluation of the statistics of the Turkish Ministry of Health shows that the rate of cesarean section in university hospitals $(69 \%)$ in 2015 was higher compared to public hospitals (37\%). ${ }^{[1]}$

There are some difficulties specific to emergency anesthesia in relation to obtaining the full medical history, full stomach, hypovolemia, pain, and limited time for patient preparation. It is, therefore, crucial to carefully perform the perioperative evaluation and treatment. To reduce these risks, emergency anesthesia should be performed by experienced anesthesiologists or under close monitoring. ${ }^{[2]}$ Evidence-based guidelines have been published on emergency anesthesia. ${ }^{[13,14]}$ In our clinic, emergency surgery is performed with individualized anesthetic management in accordance with the guideline recommendations, taking into account the patient's medical condition and type of surgery.

Better and faster organization is required to decrease morbidity and mortality in emergency surgery. When preparing for emergency surgery, an anesthesiologist must evaluate his/ her knowledge and experience, as well as the condition of the anesthetic equipment and available supplies and medications, along with the patient's condition and type of surgery. Under current conditions, COVID-19 infection should also be given the same consideration. RSI is the recommended induction method for anesthesia in patients with suspected or confirmed COVID-19. ${ }^{[15]}$ This method, which is normally applied to keep the airway open and prevent aspiration, should be applied in this group of patients to prevent the manual ventilation of the lungs and potential aerosolization. ${ }^{[16]}$ In our study, all emergency patients with suspected COVID- 19 were safely intubated using RSI.

Video laryngoscopy is known to have high success in patients with suspected difficult intubation. ${ }^{[17]}$ Video laryngoscopy has higher intubation success in trauma and emergency patients compared to direct laryngoscopy. ${ }^{[18]}$ In particular, anesthesiologists with less experience have higher intubation success in video laryngoscopy. ${ }^{[19]}$ In addition, video laryngoscopy enables the anesthesiologist to stand further from the patient's mouth compared to direct laryngoscopy. Therefore, video laryngoscopy can be used as a frontline method for airway management during the COVID-19 outbreak to reduce the risk of unexpected difficult intubation and repeated intubation attempts. This recommendation has also been included in the guidelines of anesthesia associations. ${ }^{[20]}$ In our study, intuba- tion was performed by the most experienced anesthesiologist in the team using video laryngoscopy to prevent possible cross-infection. No difficulty was experienced in intubation. We consider that a video laryngoscope should be included in medical inventory, particularly during the pandemic period.

An article reporting experiences in Wuhan, China reported that nearly 2,000 healthcare workers were infected. ${ }^{[21]}$ Therefore, following the rules of PPE in all anesthesia procedures is critical for the continuation of healthcare. Another study investigating the risk of transmission from COVID-19 patients to anesthesiologists reported that anesthesiologists who wore category I PPE (57.1\%) developed COVID- 19 at a significantly higher rate compared to those wearing category 3 PPE $(2.7 \%)(p<0.01) \cdot{ }^{[22]}$ In our study, all anesthesia procedures of COVID- 19 suspects were performed with category 3 PPE, and no one in the anesthesia team developed this infection.

In this period, general anesthesia is recommended to reduce the risk of cough that may cause airborne particles. However, spinal anesthesia is still used as the first option for cesarean delivery, as suggested by the Chinese Society of Anesthesiology. ${ }^{[5]}$ Similarly, Zhong et al. ${ }^{[22]}$ reported that spinal anesthesia was safely performed in their study in which they investigated 49 patients with COVID-19 infection, most of whom underwent cesarean delivery. In our study, emergency operations performed during the COVID-19 pandemic included a higher rate of spinal anesthesia compared to the pre-pandemic period $(26.1 \%$ and $17.5 \%$, respectively, $p=0.025)$. Although there was no statistical difference between the groups in terms of surgical procedures, the rates of cesarean section and fracture fixation procedures were higher in the pandemic period. Spinal anesthesia is the commonly used anesthetic technique for such procedures. This may be the possible explanation of the difference of anesthetic methods between pre-pandemic and pandemic period. Furthermore, the preference of patients on the choice of anesthetic method may have changed during this period. Further studies are needed to assess the patient preference on anesthesia method during the COVID-19 pandemic.

\section{Conclusion}

The diagnosis and treatment principles of emergency surgery patients are the same as they were in the pre-pandemic period, and the standards applied under normal conditions should be maintained. The clinical data and surgical features of emergency patients during the pandemic are similar to those before the pandemic; however, the rate of spinal anesthesia is higher. PPE standards should be followed to prevent cross-infection among the anesthesiology team during anesthesia procedures for emergency operations. We consider that necessary emergency interventions can be safely performed, and COVID- 19 nosocomial infection can be prevented in the operating room by following the Ministry of Health recommendations and guidelines that are updated regularly. 
Ethics Committee Approval: This study was approved by the Istanbul Medipol University Ethics Committee (Date: 14.05.2020, Decision No: 2020/387).

Peer-review: Internally peer-reviewed.

Authorship Contributions: Concept: T.U.Y.; Design: T.U.Y.; Supervision: T.U.Y.; Resource: T.U.Y.; Materials: T.U.Y.; Data: T.U.Y.; Analysis: T.U.Y., H.Ö.; Literature search: T.U.Y., H.Ö.; Writing: T.U.Y., H.Ö.; Critical revision: H.Ö.

\section{Conflict of Interest: None declared.}

Financial Disclosure: The authors declared that this study has received no financial support.

\section{REFERENCES}

1. GlobalSurg Collaborative. Mortality of emergency abdominal surgery in high-, middle- and low-income countries. Br J Surg 2016;103:971-88.

2. World Health Organization. Timeline of WHO's Response to COVID-19. Available from: https://www.who.int/news-room/detail/ 29-06-2020-covidtimeline. [CrossRef]

3. Türkiye Cumhuriyeti Sağlık Bakanlığı. COVID-19 Acil Anestezi Yönetimi. Available from: https://covid19bilgi.saglik.gov.tr/tr/covid-19-acilanestezi-yonetimi.

4. Coimbra R, Edwards S, Kurihara H, Bass GA, Balogh ZJ, Tilsed J, et al. European Society of Trauma and Emergency Surgery (ESTES) recommendations for trauma and emergency surgery preparation during times of COVID-19 infection. Eur J Trauma Emerg Surg 2020;2020:1-7.

5. Chen X, Liu Y, Gong Y, Guo X, Zuo M, Li J, et al. Perioperative management of patients infected with the novel coronavirus: Recommendation from the joint task force of the Chinese Society of anesthesiology and the chinese association of anesthesiologists. Anesthesiology. 2020;132:130716. [CrossRef]

6. Stewart B, Khanduri P, McCord C, Ohene-Yeboah M, Uranues S, Vega Rivera F, et al. Global disease burden of conditions requiring emergency surgery. Br J Surg 2014;101:e9-22. [CrossRef]

7. Smith M, Hussain A, Xiao J, Scheidler W, Reddy H, Olugbade K Jr., et al. The importance of improving the quality of emergency surgery for a regional quality collaborative. Ann Surg 2013;257:596-602. [CrossRef]

8. Shafi S, Aboutanos MB, Agarwal S Jr., Brown CV, Crandall M, Feliciano DV, et al. Emergency general surgery: Definition and estimated burden of disease. J Trauma Acute Care Surg 2013;74:1092-7. [CrossRef]

9. Kaya Z, Arıcı S, Karaman S, Doğru S, Süren M, Karaman T, et al. Retrospective evaluation of patients who underwent urgent operation after emergency unit entrance. Van Tip Derg 2014;21:22-8.

10. Ibrahim NA, Oludara MA, Ajani A, Mustafa I, Balogun R, Idowu O, et al. Non-trauma surgical emergencies in adults: Spectrum, challenges and outcome of care. Ann Med Surg (Lond) 2015;4:325-30. [CrossRef]

11. Türkiye Cumhuriyeti Sağlık Bakanlığı. Genel Sağlık İstatistikleri Özet Bilgiler. Available from: https://rapor.saglik.gov.tr/istatistik/rapor.

12. Jensen AG, Callesen T, Hagemo JS, Hreinsson K, Lund V, Nordmark J, et al. Scandinavian clinical practice guidelines on general anaesthesia for emergency situations. Acta Anaesthesiol Scand 2010;54:922-50. [CrossRef]

13. Crewdson K, Lockey D, Voelckel W, Temesvari P, Lossius HM; EHAC Medical Working Group. Best practice advice on pre-hospital emergency anaesthesia and advanced airway management. Scand J Trauma Resusc Emerg Med 2019;27:6. [CrossRef]

14. Gray LD, Morris C. The principles and conduct of anaesthesia for emergency surgery. Anaesthesia 2013;68:14-29. [CrossRef]

15. American Society of Anesthesiologists. COVID-19 Information for Health Care Professionals. Available from: https://www.asahq.org/ about-asa/governance-and-committees/asa-committees/committee-on-occupational-health/coronavirus.

16. Kim HJ, Ko JS, Kim TY. Recommendations for anesthesia in patients suspected of COVID-19 coronavirus infection. Korean J Anesthesiol 2020;73:89-91. [CrossRef]

17. Apfelbaum JL, Hagberg CA, Caplan RA, Blitt CD, Connis RT, Nickinovich DG, et al. Practice guidelines for management of the difficult airway: An updated report by the American society of anesthesiologists task force on management of the difficult airway. Anesthesiology 2013;118:251-70. [CrossRef]

18. Michailidou M, O'Keeffe T, Mosier JM, Friese RS, Joseph B, Rhee P, et al. A comparison of video laryngoscopy to direct laryngoscopy for the emergency intubation of trauma patients. World J Surg 2015;39:782-8. [CrossRef]

19. Suzuki K, Kusunoki S, Tanigawa K, Shime N. Comparison of three video laryngoscopes and direct laryngoscopy for emergency endotracheal intubation: A retrospective cohort study. BMJ Open 2019;9:e024927.

20. World Federation of Societies of Anaesthesiologists. Coronavirus Guidance for Anaesthesia and Perioperative Care Providers. Available from: https://www.wfsahq.org/resources/coronavirus.

21. Meng L, Qiu H, Wan L, Ai Y, Xue Z, Guo Q, et al. Intubation and ventilation amid the COVID-19 outbreak: Wuhan's experience. Anesthesiology 2020;132:1317-32. [CrossRef]

22. Zhong Q, Liu YY, Luo Q, Zou YF, Jiang HX, Li H, et al. Spinal anaesthesia for patients with coronavirus disease 2019 and possible transmission rates in anaesthetists: Retrospective, single-centre, observational cohort study. Br J Anaesth 2020;124:670-5. [CrossRef] 
ORİJiNAL ÇALIŞMA - ÖZ

\section{COVID-19 pandemi öncesi ve pandemi dönemlerindeki acil ameliyatlarının ve acil cerrahi anestezi yöntemlerinin değerlendirilmesi \\ Dr. Tümay Uludağ Yanaral, Dr. Hüseyin Öz}

İstanbul Medipol Üniversitesi Tıp Fakültesi, Anesteziyoloji ve Reanimasyon Anabilim Dalı, İstanbul

AMAÇ: Koronavirüs hastalı̆̆ 2019 (COVID-19) pandemisini takiben eğitime ara verilmesi, sosyal izolasyon ve sokağa çıkma kısıtlamaları gibi bulaş riskini azaltmaya yönelik alınan önlemler sonucunda toplumda aktif rol alan insan sayısında azalma olmuştur. Bunun sonucu olarak acil cerrahi etiyolojisinde bir değişiklik olacağı düşünülebilir. Bu çalışmada, COVID-19 pandemi öncesi ve pandemi dönemlerinde hastanemizde yapılan acil ameliyatları ve acil cerrahi anestezi yöntemlerini değerlendirmeyi ve şüpheli COVID- 19 enfeksiyonu olan hastaların acil anestezi yönetimini sunmayı amaçladık.

GEREÇ VE YÖNTEM: 22 Ocak-29 Nisan 2020 tarihleri arasında hastanemizde acil ameliyat olan hastalar geriye dönük olarak incelendi. Hastalar, I I Mart 2020 tarihi öncesinde ameliyat olanlar (Grup I) ve sonrasında ameliyat olanlar (Grup 2) olarak iki gruba ayrıldı. İki grup verileri karşılaştırıldı. Grup I'deki tüm hastalara ve Grup 2'de COVID-19 şüphesi olmayanlara rutin acil anestezi ve cerrahi yaklaşım uygulandı. Grup 2'de COVID-19 şüphesi olan hastalar, resmî kurumların ve bilimsel derneklerin kılavuzlarına uygun olarak oluşturulan algoritma ile tedavi edildi.

BULGULAR: Yaş, cinsiyet, kronik hastalıklar, ASA sınıflaması, Mallampati skoru, cerrahi branş, cerrahi prosedürler, cerrahi etiyolojisi, ameliyat süresi ve hastanede yatış süresi her iki grupta benzerdi. Genel anestezi ve spinal anestezi uygulanan hasta sayısı Grup I için sırasıyla 198 (\%82.5) ve 42 (\% 17.5), Grup 2 için sırasıyla I6I (\%73.9) ve 57 (\%26. I) idi ( $p=0.025)$.

TARTIŞMA: Pandemi döneminde ki acil hastaların klinik verileri ve cerrahi ilişkili özellikleri pandemi öncesi acil hastalar ile benzerdir ancak pandemi döneminde daha fazla spinal anestezi uygulanmıştır. Acil anestezi uygulamaları sonucu anestezi ekibinde çapraz enfeksiyon gözlenmemesi için kişisel koruyucu ekipman kurallarına uyulmalıdır. T.C. Sağlık Bakanlığı'nın düzenli olarak güncellenen tavsiyelerine ve kılavuz önerilerine uyularak ameliyathanede gerekli acil müdahalelerin güvenli bir şekilde yapılabileceğini ve COVID-I9 nozokomiyal enfeksiyonunun önlenebileceğini düşünüyoruz. Anahtar sözcükler: Aciller; anestezi; cerrahi; COVID-19; koronavirüs enfeksiyonları.

Ulus Travma Acil Cerrahi Derg 2021;27(6):639-646 doi: 10.14744/tjtes.2020.43678 